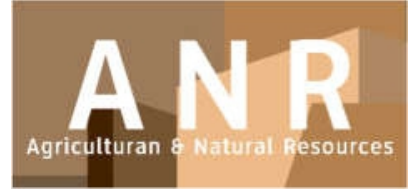

PAPER - OPEN ACCESS

\title{
Membangun Kemitraan Kehutanan pada Kawasan Hutan Dengan Tujuan Khusus (KHDTK) Mengkendek, Kabupaten Tana Toraja, Sulawesi Selatan
}

\author{
Author $\quad$ : Abd. Kadir Wakka dan Achmad Rizal H. Bisjoe \\ DOI $\quad: 10.32734 /$ anr.v2i1.569 \\ Electronic ISSN $\quad: 2654-7023$ \\ Print ISSN $\quad: 2654-7015$
}

Volume 2 Issue 1 - 2019 TALENTA Conference Series: Agricultural and Natural Resources (ANR)

This work is licensed under a Creative Commons Attribution-NoDerivatives 4.0 International License.

Published under licence by TALENTA Publisher, Universitas Sumatera Utara

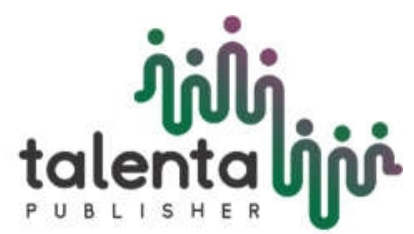




\title{
jidi i r (a) \\ ANR Conference Series 02 (2019)

\section{Membangun Kemitraan Kehutanan pada Kawasan Hutan Dengan Tujuan Khusus (KHDTK) Mengkendek, Kabupaten Tana Toraja, Sulawesi Selatan}

\author{
(Building of Forest Partnerships in Mengkendek KHDTK (Forests area with Special \\ Purpose), Tana Toraja District, South Sulawesi)
}

\author{
Abd. Kadir Wakka ${ }^{1 *}$ dan Achmad Rizal H. Bisjoe ${ }^{1}$ \\ ${ }^{1}$ Balai Penelitian dan Pengembangan Lingkungan Hidup dan Kehutanan, Makassar \\ Jl. Perintis Kemerdekaan Km. 16,5 Makassar, 90243 \\ Email: abdkadirw@gmail.com
}

\begin{abstract}
Abstrak
Fungsi Kawasan Hutan dengan Tujuan Khusus (KHDTK) Mengkendek sebagai hutan penelitian menjadi optimal apabila areal tersebut terbebas dari konflik kepentingan khususnya dengan masyarakat sekitar. Salah satu upaya yang dapat dilakukan untuk mengatasi konflik kepentingan di KHDTK Mengkendek adalah melalui kemitraan kehutanan. Kemitraan kehutanan selain sebagai salah satu bentuk resolusi konflik, juga merupakan upaya pemberdayaan masyarakat sekitar hutan melalui pemberian akses dalam pemanfaatan sumber daya hutan dengan tetap memperhatikan fungsi hutan yang ada. Penelitian ini bertujuan memberikan gambaran proses membangun kemitraan kehutanan di KHDTK Mengkendek. Penelitian dilakukan dengan menggunakan pendekatan Participatory Action Research (PAR). Hasil penelitian menunjukkan bahwa proses membangun kemitraan kehutanan di KHDTK Mengkendek dibagi ke dalam empat tahap yaitu tahap identifikasi kepentingan para pihak, tahap identifikasi peran para pihak dalam kemitraan kehutanan, tahap penyusunan skenario/model kemitraan, dan tahap penyusunan naskah kesepakatan kemitraan kehutanan di KHDTK Mengkendek. Partisipasi aktif semua stakeholders dalam setiap tahapan yang ada, akan menjadikan kemitraan kehutanan dapat diimplementasikan dengan baik sehingga fungsi KHDTK Mengkendek menjadi optimal dan masyarakat setempat tetap mendapatkan manfaat dari areal KHDTK Mengkendek.
\end{abstract}

Kata kunci: kemitraan kehutanan, KHDTK Mengkendek, konflik kepentingan, Participatory Action Research, partisipasi stakeholders;

\begin{abstract}
Forest area with special purpose or its famous terminology in Indonesia KHDTK, of Mengkendek can be optimally managed if there is no conflict of interest among the stakeholders, especially with the people around and within the KHDTK. The forestry partnership program is an alternative solution that offered by the Ministry of Environment and Forestry in overcoming the conflict. Besides that, this program aims to empower the people around and within the forest included KHDTK by providing access to participate in managing the forest and maintaining its function as well. This study aims to provide an overview of the establishing forestry partnership process in the KHDTK Mengkendek. The Participatory Action Research (PAR) approaches was applying in this study. The results showed that there are four (4) stages in the process, namely: (i) identifying the parties' interests; (ii) identifying the parties' roles in the partnership; (iii) preparing the partnership scenario/model; and (iv) drafting the concept of forestry partnership agreement of KHDTK Mengkendek. The active participation of all stakeholders in each stage will boost the forestry partnership well implemented, so KHDTK Mengkendek can be well managed and the people around and within this area can obtain the sustainable benefit from the KHDTK.
\end{abstract}

Keywords: forestry partnership, KHDTK Mengkendek, conflict of interest, Participatory Action Research, stakeholder participation;

(C) 2019 The Authors. Published by TALENTA Publisher Universitas Sumatera Utara

Selection and peer-review under responsibility of Pertemuan Ilmiah Tahunan (PIT) dan Seminar Nasional Ke-4,

Komunitas Manajemen Hutan Indonesia (KOMHINDO)

p-ISSN: 2654-7015, e-ISSN: 2654-7023, DOI: 10.32734/anr.v2i1.569 


\section{Pendahuluan}

Laju deforestasi hutan di Indonesia dalam kurung waktu Tahun 2000 - 2009 mencapai 1,5 juta ha/tahun [1]. Deforestasi hutan umumnya dapat disebabkan oleh peristiwa alam seperti cuaca ekstrim, kekeringan dan atau kebakaran hutan [2] dan dapat pula disebabkan oleh penguasaan dan pemanfaatan lahan yang dilakukan oleh manusia [3] untuk berbagai kepentingan seperti untuk pembangunan pertanian [4], perkebunan kelapa sawit [5], pemukiman dan pembukaan jalan [6]. Intinya adalah terjadi perbedaan kepentingan dalam pengelolaan dan pemanfaatan sumberdaya hutan.

Kawasan Hutan dengan Tujuan Khusus adalah kawasan hutan yang ditetapkan oleh pemerintah untuk tujuan penelitian, pendidikan dan pelatihan serta religi. Balai Penelitian dan Pengembangan Lingkungan Hidup dan Kehutanan (BP2LHK) Makassar berdasarkan Surat Keputusan Menteri Kehutanan (SK Menhut) No. 367/MenhutII/2004 mengelola 3 KHDTK dan salah satu diantaranya adalah KHDTK Mengkendek di Kabupaten Tana Toraja, Sulawesi Selatan dengan luas areal mencapai 100 ha [7]. Tujuan pengelolaan KHDTK Mengkendek berdasarkan SK Menhut tersebut di atas adalah untuk kegiatan penelitian dan pengembangan kehutanan.

Perbedaan kepentingan turut mewarnai pengelolaan KHDTK Mengkendek. Hal ini terjadi karena lokasinya KHDTK Mengkendek berbatasan dengan pemukiman penduduk dan kota Ge'tengan, Kecamatan Mengkendek, Kabupaten Tana Toraja serta menjadi lahan garapan bagi masyarakat dalam menenuhi kebutuhan hidup [8][9][10]. Perbedaan kepentingan yang terjadi harus ditangani dengan baik karena dapat menghambat pelaksanaan fungsi KHDTK sebagai hutan penelitian serta mengancam kelestarian hutan yang terdapat di dalamnya [11].

Salah satu upaya yang ditempuh untuk mengatasi konflik kepentingan di KHDTK Mengkendek adalah melalui kemitraan kehutanan. Selain untuk mengatasi konflik kepentingan, kemitraan Kehutanan juga menjadi salah satu upaya untuk memberdayakan masyarakat di dalam dan sekitar hutan [12][13]. Hal ini tertuang pula dalam Peraturan Menteri Lingkungan Hidup dan Kehutanan (Permenlhk) No. P.84/Menlhk-Setjen/2015 tentang Penanganan Konflik Tenurial Kawasan Hutan. Dalam Permenlhk tersebut disebutkan bahwa salah satu upaya penyelesaian konflik tenurial kawasan hutan adalah melalui perhutanan sosial. Bentuk perhutanan sosial dapat berupa kemitraan kehutanan sebagaimana disebutkan dalam Permenlhk No. P.83/Menlhk/Setjen/Kum.1/10/2016 tentang Perhutanan Sosial.

Kemitraan kehutanan akan berjalan dengan baik apabila proses membangun kemitraan tersebut dilakukan dengan baik [12][13]. Proses membangun kemitraan kehutanan yang dilaksanakan dengan baik dan melibatkan semua pihak yang berkepentingan dalam pengelolaan KHDTK Mengkendek akan membuat semua pihak memiliki persepsi yang sama dan sehingga memiliki peluang yang cukup besar untuk mendapatkan dukungan dari berbagai pihak untuk diimplementasikan.

Penelitian ini bertujuan memberikan gambaran proses membangun kemitraan kehutanan di KHDTK Mengkendek, Kabupaten Tana Toraja, Provinsi Sulawesi Selatan. Penelitian ini diharapkan menjadi bahan pertimbangan dan pembelajaran bersama dalam membangun kemitraan kehutanan antara pengelola hutan dengan masyarakat sekitar.

\section{Metode Penelitian}

\subsection{Lokasi dan Waktu Penelitian}

Penelitian dilaksanakan pada KHDTK Mengkendek yang secara administrasi terletak di Kelurahan Rantekalua dan Kelurahan Tampo, Kecamatan Mengkendek, Kabupaten Tana Toraja, Sulawesi Selatan (Gambar 1). Penelitian dilaksanakan dalam kurung waktu tahun 2015 - 2017. 


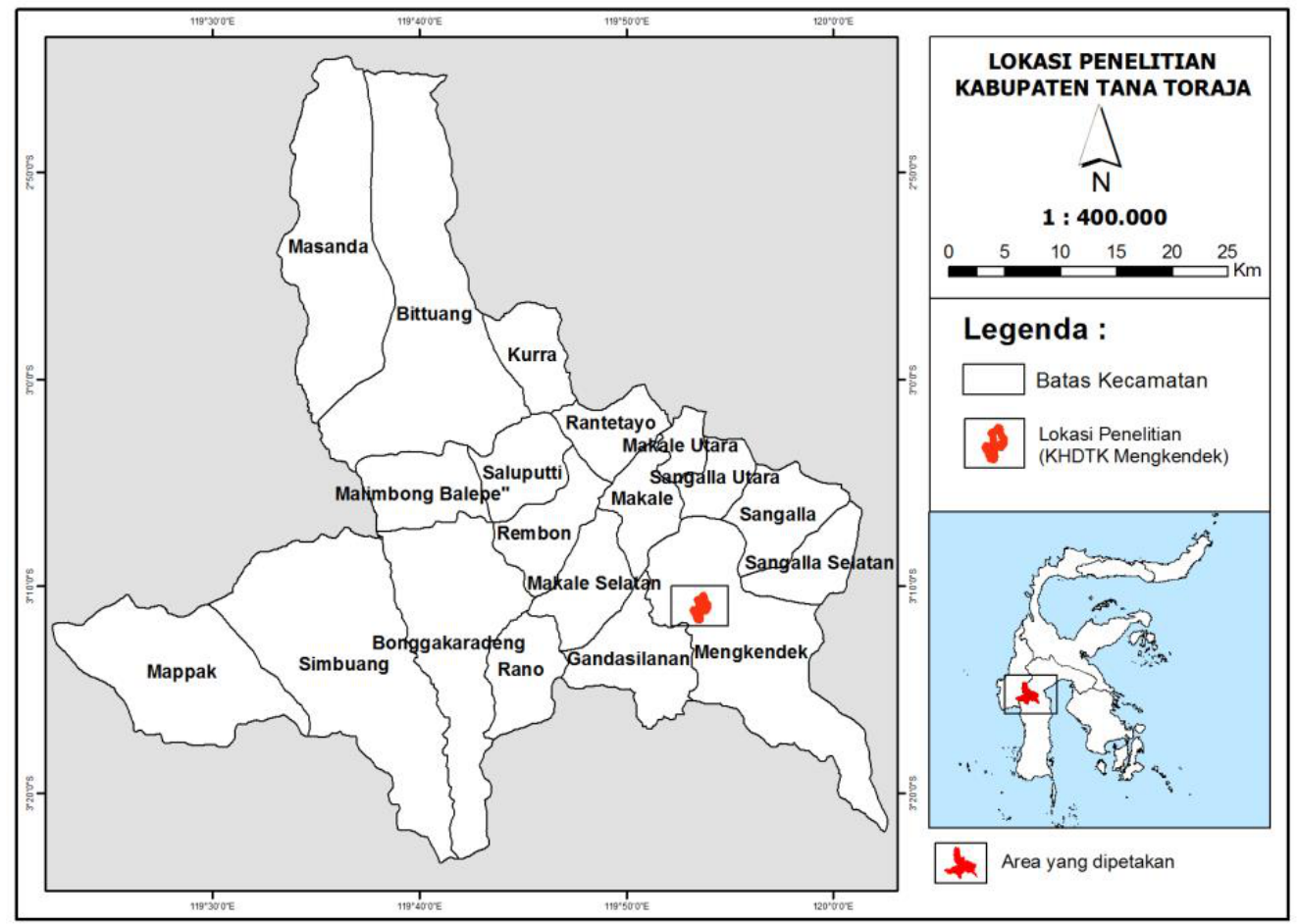

Gambar 1. Lokasi penelitian

\subsection{Pengumpulan Data}

Penelitian ini merupakan penelitian deskriptif dengan metoda PAR (Participatory Action Research) yang merupakan perpaduan antara penelitian (research), pembelajaran (education) dan tindakan (action) dalam pengumpulan data dan informasi khususnya pada isu-isu sosial atau lingkungan [14][15]. Pendekatan PAR merupakan suatu proses yang berulang mulai dari penyusunan rencana, pelaksanaan sambil mengamati proses yang berlangsung serta melakukan refleksi atas proses yang berlangsung sebagai bahan dalam menyusun rencana berikutnya [16] sebagaimana ditunjukkan pada Gambar 2. Dalam penelitian ini, tim peneliti selain berperan sebagai peneliti yang bertugas mengumpulkan dan menganalisis data, juga berperan sebagai fasilitator dan mediator dalam mempertemukan semua pihak yang berkepentingan untuk kemudian bersama-sama merumuskan konsep kemitraan di KHDTK Mengkendek.

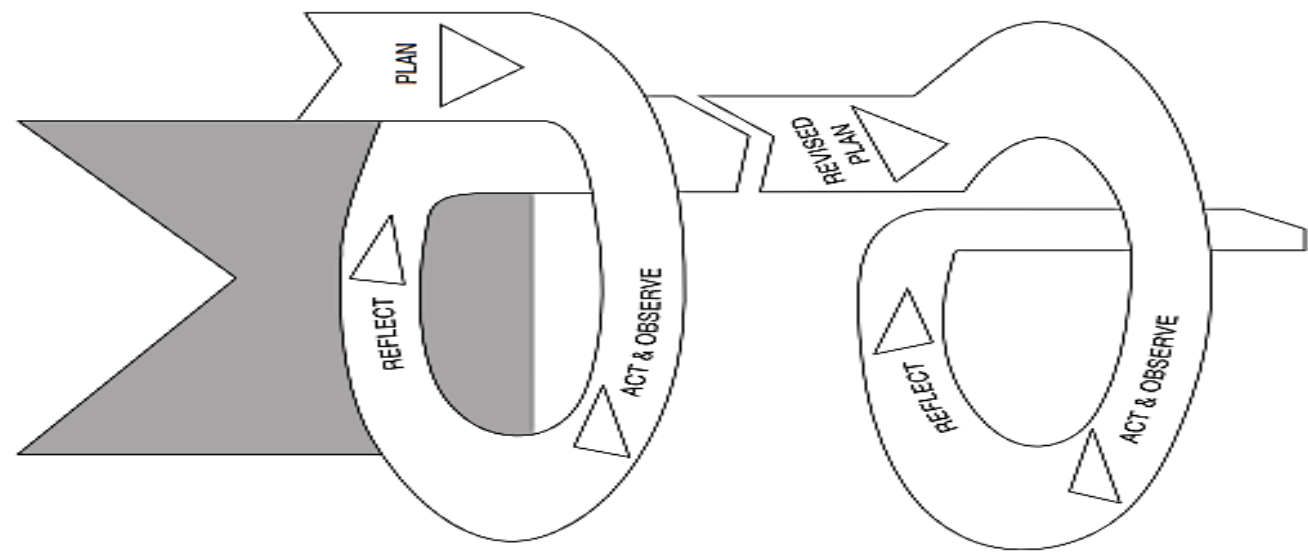

Gambar 2. The action research spiral [16] 
Untuk mencapai tujuan penelitian, maka dilakukan pengumpulan data melalui kegiatan wawancara dengan informan kunci dan focus group discussion (FGD) atau dialog para pihak. Kegiatan wawancara informan kunci (terdiri dari staf BP2LHK Makassar, Dinas Kehutanan dan Perkebunan Kabupaten Tana Toraja, Aliansi Masyarakat Adat Nusantara-AMAN Tana Toraja, pemda setempat, tokoh adat/tokoh masyarakat dan masyarakat sekitar KHDTK) dimaksudkan untuk mendapatkan informasi mengenai para pihak terkait (stakeholders) beserta kepentingannya sehingga diperoleh gambaran isu konflik kepentingan dalam pengelolaan KHDTK Mengkendek dan upaya penyelesaiannya. Sementara kegiatan FGD yang melibatkan pengelola KHDTK, Dinas Kehutanan dan Perkebunan Kabupaten Tana Toraja, pemda setempat, tokoh adat/tokoh masyarakat dan masyarakat sekitar KHDTK dimaksudkan untuk mengklarifikasi isu konflik kepentingan yang berkembang berdasarkan hasil wawancara informan kunci, merumuskan peran para pihak dalam pengelolaan KHDTK Mengkendek dan merumuskan konsep naskah kemitraan kehutanan pengelolaan KHDTK Mengkendek.

\subsection{Analisis Data}

Data yang terkumpul melalui kegiatan wawancara informan dan FGD dianalisis secara deskriptif kualitatif [17]. Adapun proses analisis deskriptif kualtiatatif adalah; 1) mengumpulkan dan memilah-milah data sesuai dengan konsep, kategori atau tema; 2) menyajikan data dan informasi; dan 3) penarikan kesimpulan sesuai tujuan penelitian. Proses analisis deskriptif kualitatif ditunjukkan pada Gambar 3.

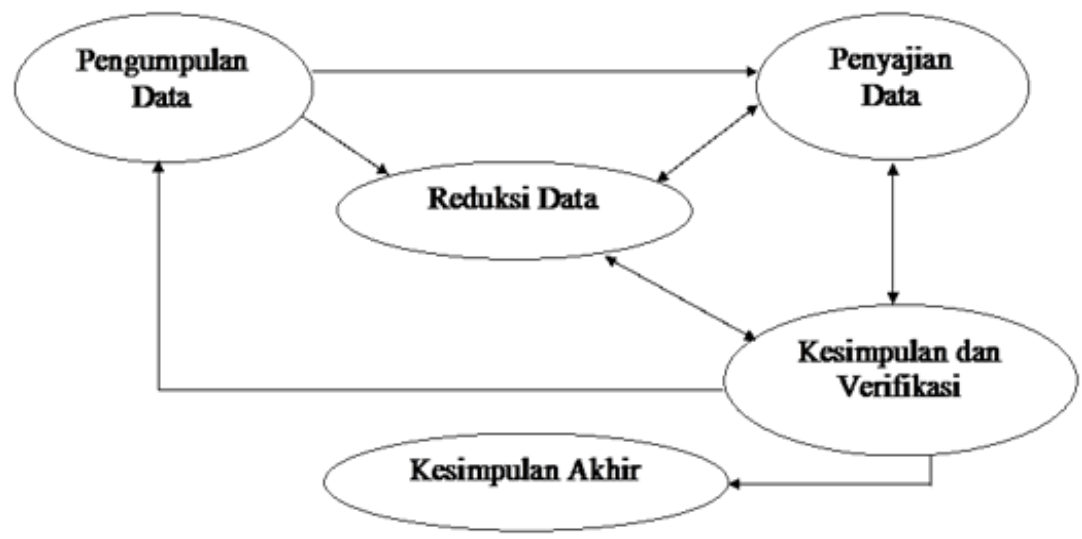

Gambar 3. Proses analisis data kualitatif [17]

\section{Hasil dan Pembahasan}

\subsection{Pengelolaan Konflik di KHDTK Mengkendek}

KHDTK Mengkendek merupakan bagian dari Hutan Mapongka Kabupaten Tana Toraja yang sejak tahun 1994 ditunjuk menjadi Stasiun Penelitian dan Ujicoba (SPUC) berdasarkan SK Menhut No. 275/Kpts-1/1994 dengan luas wilayah mencapai 100 ha. Pada tahun 2004, SPUC kemudian berubah nama menjadi KHDTK Mengkendek berdasarkan SK Menhut No. 367/Menhut-II/2004. Secara administasi pemerintahan, KHDTK Mengkendek masuk dalam wilayah kelurahan Tampo dan Kelurahan Rantekalua, Kecamatan Mengkendek, Kabupaten Tana Toraja, Sulawesi Selatan [7].

Perbedaan kepentingan antara masyarakat sekitar dengan pengelola KHDTK Mengkendek telah terjadi sejak areal tersebut ditunjuk menjadi SPUC. Perbedaan kepentingan merupakan penyebab terjadinya konflik [18][19] antara masyarakat dengan pengelola KHDTK. Masyarakat sekitar KHDTK mengklaim areal KHDTK Mengkendek sebagai tanah adat ataupun tanah warisan turun temurun [8][9][20][21][10]. Sebagian masyarakat sekitar telah memanfaatkan areal tersebut untuk berkebun dan sebagian lainnya hanya sekedar memberikan patok penanda batas penguasaan. Konflik kepentingan yang terjadi di KHDTK Mengkendek menyebabkan fungsi KHDTK Mengkendek 
sebagai hutan penelitian dan pengembangan kehutanan tidak berjalan secara optimal karena mendapatkan gangguan dari masyarakat sekitar serta menyebabkan kerusakan ekosistem hutan karena terjadinya penebangan illegal [8][9].

Berbagai pendekatan telah ditempuh pengelola KHDTK dalam menyelesaikan konflik yang terjadi mulai dari penegakan hukum sampai pada pendekatan dialog atau mediasi. Pendekatan dialog/mediasi pada akhirnya menjadi pilihan pengelola KHDTK Mengkendek setelah pendekatan penegakan hukum dirasakan tidak efektif menyelesaikan konflik kepentingan yang terjadi. Pendekatan dialog/mediasi telah merumuskan kemitraan kehutanan sebagai bentuk resolusi konflik di KHDTK Mengkendek [20][21]. Pendekatan yang ditempuh oleh pengelola KHDTK dalam menyelesaikan konflik di KHDTK Mengkendek sebagaimana ditunjukkan pada Gambar 4.

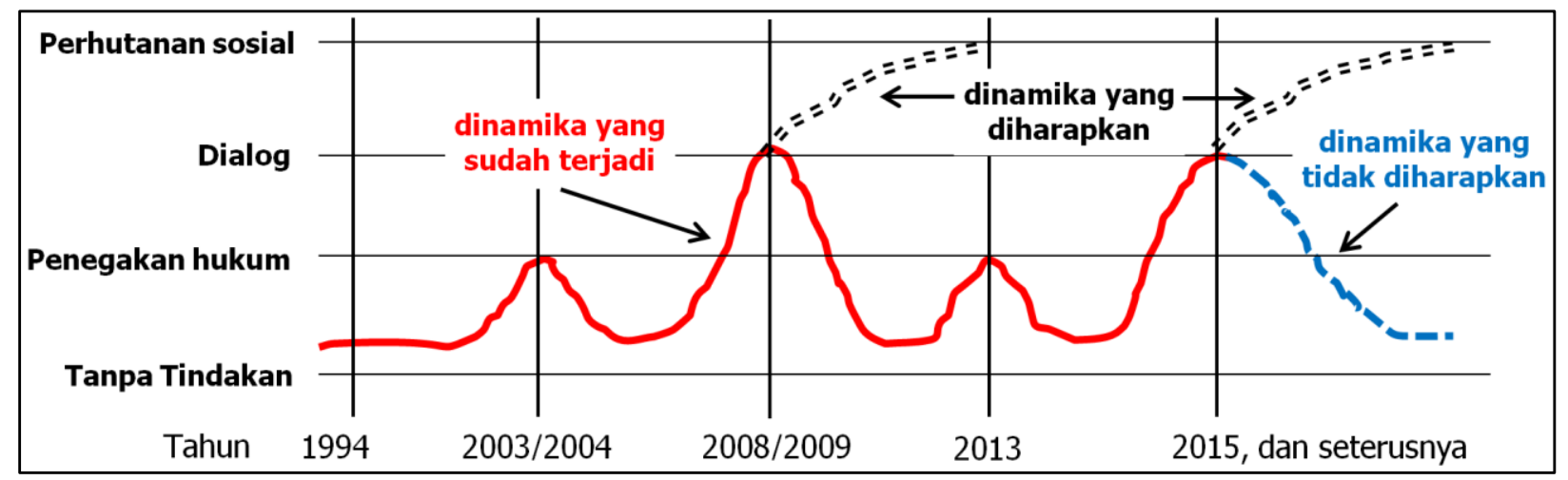

Gambar 4. Pendekatan penyelesaian konflik di KHDTK Mengkendek [20]

\subsection{Proses Membangun Kemitraan Kehutanan di KHDTK Mengkendek}

Membangun kemitraan kehutanan sebagai bentuk resolusi konflik kepentingan dalam pengelolaan KHDTK Mengkendek memerlukan waktu yang panjang. Pendekatan partisipatif menjadi pilihan yang digunakan dalam proses membangun kemitraan kehutanan tersebut. Pendekatan partisipatif adalah pendekatan yang menekankan keterlibatan aktif masyarakat atau pihak terkait lainnya dalam setiap proses suatu program atau kegiatan [22]. Bentuk keterlibatan yang diharapkan dapat dalam bentuk pengumpulan atau pemberian informasi atau dalam bentuk memberikan alternatif rencana dan usulan kegiatan [23] bahkan dalam proses perumusan dan pengambilan keputusan serta pelaksanaannya [24]. Melalui pendekatan partisipatif, diharapkan semua pihak yang terkait akan lebih memahami maksud, tujuan dan manfaat kemitraan kehutanan di KHDTK Mengkendek sehingga mereka akan mendukung dan mengusahakan kemitraan kehutanan terwujud.

Proses membangun kemitraan kehutanan di KHDTK Mengkednek sebagaimana ditunjukkan pada Gambar 5 diawali dengan identifikasi para pihak (stakeholders) yang berkepentingan dalam pengelolaan KHDTK Mengkendek. Hasil identifikasi para pihak (stakeholders) menunjukkan bahwa pihak yang berkepentingan terhadap pengelolaan KHDTK Mengkendek diantaranya BP2LHK Makassar, lembaga adat Tampo, Dinas Kehutanan dan Perkebunan Kabupaten Tana Toraja, Pemda setempat (kelurahan/lembang dan kecamatan) dan masyarakat sekitar KHDTK. BP2LHK Makassar, lembaga adat Tampo, Dinas Kehutanan dan Perkebunan Kabupaten Tana Toraja dan pemda setempat merupakan stakeholders yang memiliki kepentingan dan pengaruh yang besar dalam pengelolaan KHDTK (key players). Sementara masyarakat sekitar KHDTK merupakan stakeholder yang memiliki kepentingan dan pengaruh yang kecil dalam pengelolaan KHDTK (crowd) [9].

Kepentingan BP2LHK Makassar terhadap KHDTK Mengkendek adalah memastikan fungsi KHDTK sebagai hutan penelitian dan pengembangan kehutanan berjalan dengan optimal, serta tidak terjadi kerusakan hutan di KHDTK. Kepentingan Dinas Kehutanan dan Perkebunan Kabupaten Tana Toraja adalah memastikan kelestarian kawasan hutan yang ada di wilayah kerjanya tetap terjaga. Sementara itu, Lembaga Adat Tampo berkepentingan dalam menjamin terpenuhinya hak-hak masyarakat Tampo akan sumberdaya lahan yang terdapat di wilayah 
adatnya. Sedangkan pemda setempat sangat berkepentingan dalam meningkatkan kesejahteraan masyarakatnya melalui pemanfaatan sumberdaya hutan yang terdapat di KHDTK Mengkendek.

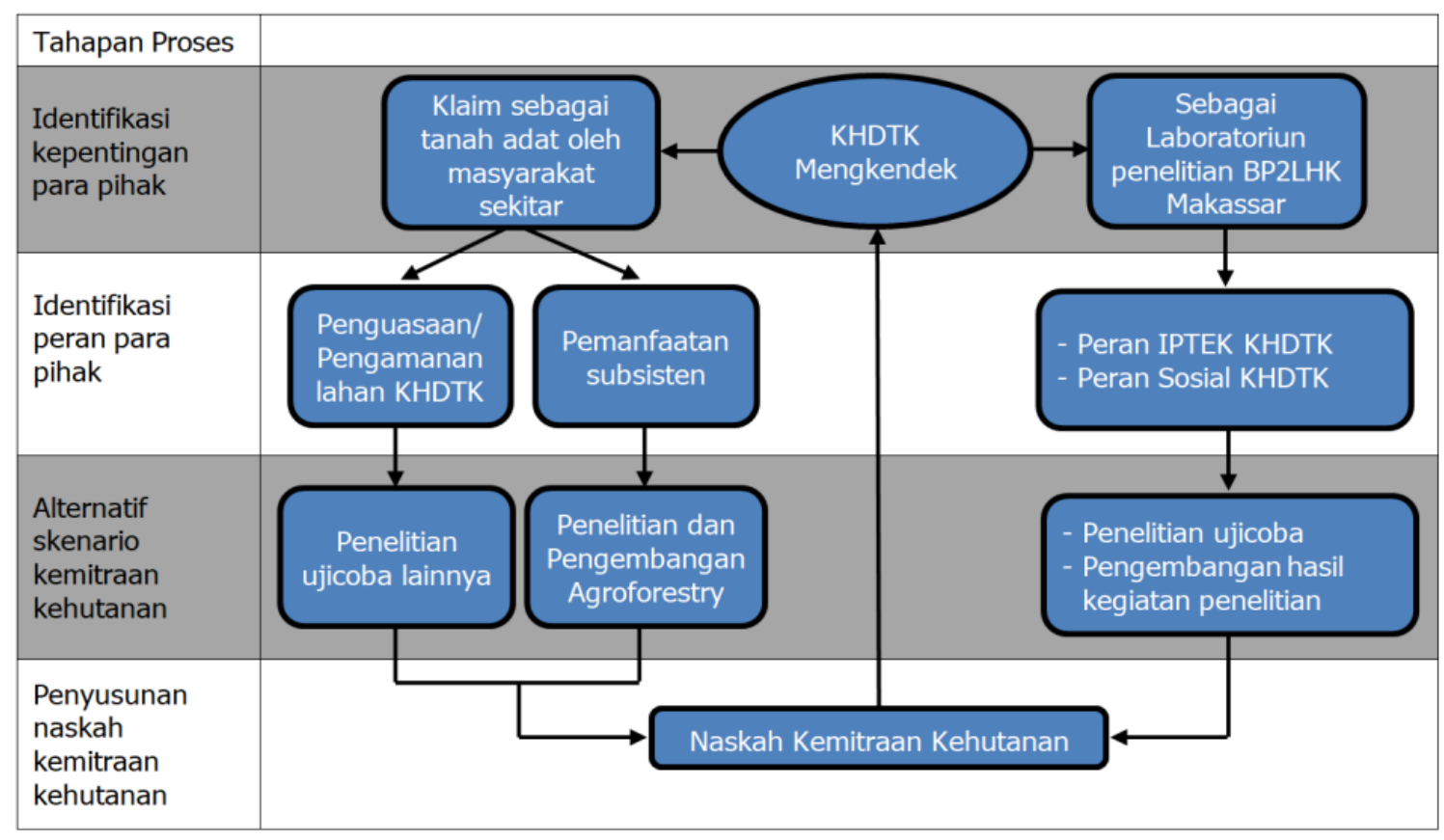

Gambar 5. Proses membangun kemitraan kehutanan di KHDTK Mengkendek

Setelah tahap identifikasi stakeholders beserta kepentingannya dalam pengelolaan KHDTK selesai kemudian dilanjutkan dengan tahap identifikasi peran stakeholders dalam pengelolaan KHDTK Mengkendek. Hasil FGD menunjukkan bahwa dari lima stakeholders yang telah diidentifikasi pada tahap sebelumnya, Lembaga Adat Tampo/tokoh adat, masyarakat sekitar KHDTK dan BP2LHK Makassar merupakan aktor utama yang diharapkan berperan besar dalam pengelolaan KHDTK Mengkendek khususnya dalam implementasi kemitraan kehutanan.

Fungsi KHDTK sebagai hutan penelitian dan pengembangan kehutanan diharapkan dapat membantu dalam menghasilkan paket ilmu pengetahuan dan teknologi (IPTEK) yang bermanfaat bagi pengembangan kehutanan. Selain itu, KHDTK Mengkendek diharapkan memberikan manfaat bagi masyarakat sekitar dalam upaya meningkatkan kesejahteraannya melalui pemberian akses pemanfaatan sumberdaya hutan yang terdapat di dalamnya. Peran sebagai penyedia IPTEK dan fungsi sosial KHDTK akan diemban oleh pengelola KHDTK Mengkendek dalam hal ini BP2LHK Makassar.

Penguasaan areal KHDTK Mengkendek oleh Lembaga Adat Tampo/tokoh-tokoh adat melalui klaim tanah adat diharapkan tidak menghambat fungsi KHDTK sebagai hutan penelitian dan pengembangan kehutanan. Penguasaan lahan yang dilakukan oleh tokoh-tokoh adat diharapkan dapat membantu membendung masuknya "orang luar" untuk mengokupasi dan merusak areal KHDTK Mengkendek. Tokoh-tokoh adat diharapkan dapat membantu mengkomunikasikan atau mensosialisasikan program-program dari pengelola KHDTK (BP2LHK Makassar) dalam mendukung kemitraan kehutanan kepada masyarakat sekitar KHDTK Mengkendek.

Sebagian masyarakat sekitar KHDTK telah memanfaatkan areal KHDTK untuk kebutuhan subsisten. Peran pemanfaatan subsisten tersebut masih dapat dilanjutkan selama sesuai aturan yang berlaku. Melalui peran pemanfaatan subsisten oleh masyarakat sekitar, diharapkan mereka dapat pula membantu mengamankan areal KHDTK dari kerusakan dan pengrusakan.

Tahapan selanjutnya adalah penyusunan skenario kemitraan. Kepentingan dan peran para pihak dalam pengelolaan KHDTK Mengkendek sedapat mungkin terwadahi dalam skenario kemitraan kehutanan tersebut. Upaya BP2LHK Makassar dalam melaksanakan perannya sebagai penyedia IPTEK bagi pembangunan kehutanan dan kesejahteraan masyarakat serta mewujudkan fungsi KHDTK sebagai laboratorium penelitian dan fungsi sosial 
KHDTK Mengkendek, maka jaminan akan ketersediaan lahan dan keamanan dalam melakukan kegiatan penelitian sangat penting. Lahan-lahan yang hanya diklaim sebagai tanah adat dan tidak diolah secara intensif akan diperuntukkan untuk lokasi kegiatan ujicoba atau lokasi pembuatan demplot penelitian. Lahan-lahan yang digarap intensif oleh masyarakat akan dijadikan areal penelitian dan pengembangan agroforestry. Skenario kemitraan kehutanan sebagaimana disebutkan di atas kemudian dituangkan dalam naskah kemitraan kehutanan yang penyusunannya melibatkan semua stakeholders yang terlibat dalam pengelolaan KHDTK Mengkendek.

\section{Kesimpulan}

Kemitraan kehutanan menjadi pilihan pengelola KHDTK Mengkendek dalam menyelesaikan konflik kepentingan yang terdapat di KHDTK Mengkendek. Dibutuhkan waktu yang cukup panjang dalam membangun kemitraan kehutanan di KHDTK Mengkendek. Proses membangun kemitraan kehutanan di KHDTK Mengkendek dibagi dalam empat tahap yaitu tahap identifikasi kepentingan para pihak, tahap merumuskan peran para pihak dalam kemitraan kehutanan, tahap penyusunan skenario/model kemitraan kehutanan, dan tahap penyusunan naskah kesepakatan kemitraan kehutanan di KHDTK Mengkendek. Semua stakeholder yang berkepentingan terlibat aktif dalam setiap tahapan. Keterlibatan semua stakeholder pada keempat tahapan yang ada, diharapkan tercipta kesamaan persepsi tentang kemitraan kehutanan dapat diimplementasikan dengan baik sehingga fungsi KHDTK dapat berjalan secara optimal dan masyarakat setempat tetap mendapatkan manfaat dari areal KHDTK Mengkendek.

Kemitraan kehutanan yang sedang dibangun di KHDTK Mengkendek sedapat mungkin menjadi bagian dari program perhutanan sosial pada Balai Perhutanan Sosial dan Kemitraan Lingkungan (Balai PSKL) Wilayah Sulawesi. Melalui integrasi program perhutanan sosial pada Balai PSKL Wilayah Sulawesi, diharapkan kemitraan kehutanan di KHDTK Mengkendek akan mendapatkan bantuan proses fasilitasi yang sedang berlangsung dan bantuan dalam program pemberdayaan masyarakat bagi masyarakat sekitar KHDTK Mengkendek

\section{Ucapan Terima Kasih}

Penelitian ini terlaksana dengan baik berkat dukungan dari berbagai pihak. Untuk itu, apresiasi yang sebesarbesarnya dan ucapan terima kasih disampaikan kepada Kepala BP2LHK Makassar atas kesempatan yang diberikan untuk melaksanakan penelitian, anggota tim: Bugi K. Sumirat, Andarias Ruru, Hamdan dan Supardi yang telah membantu dalam kegiatan pengumpulan data, Kepala seksi sarana penelitian BP2LHK Makassar beserta staf, Kepala Dinas Kehutanan dan Perkebunan Tana Toraja, Camat Mengkendek, Lurah Rante Kalua', Lurah Tampo, tokoh adat dan tokoh masyarakat serta masyarakat sekitar KHDTK Mengkendek atas kerjasama yang baik dalam pelaksanaan penelitian ini.

\section{Referensi}

[1] Sumargo, W., Nanggara, S. G., Nainggolan, F. A., \& Apriani, I. 2011. Potret Keadaan Hutan Indonesia Periode Tahun $2000-2009$. Bogor: Forest Watch Indonesia.

[2] Eckert, S., Ratsimba, H. R., Rakotondrasoa, L. O., Rajoelison, L. G., \& Ehrensperger, A. 2011. Deforestation and forest degradation monitoring and assessment of biomass and carbon stock of lowland rainforest in the Analanjirofo region, Madagascar. Forest Ecology and Management, 262(11), 1996-2007.

[3] Handoko, \& Darmawan, A. 2015. "Perubahan tutupan hutan di Taman Hutan Raya Wan Abdul Rachman (Tahura WAR)". Jurnal Sylva Lestari, 3(2), 43-52.

[4] Ting, Z., Haiyun, C., Shivakoti, G. P., Cochard, R., \& Homcha-aim, K. 2011. "'Thailand: Changes in status and utilization". Environment, Development and Sustainability, 13(2), 385-402.

[5] Margono, B. A., Potapov, P. V., Turubanova, S., Stolle, F., \& Hansen, M. C. 2014. "Primary forest cover loss in Indonesia over 20002012". Nature Climate Change, 4(June), 1-6. http://doi.org/10.1038/NCLIMATE2277

[6] Geist, H. J., \& Lambin, E. F. 2002. Proximate Causes and Underlying Driving Forces of Tropical Deforestation. BioScience, $52(2), 143$. http://doi.org/10.1641/0006-3568(2002)052[0143:PCAUDF]2.0.CO;2.

[7] BPPKS. 2006. "Rencana Pengelolaan Kawasan Hutan dengan Tujuan Khusus (KHDTK)". Makassar: Balai Penelitian dan Pengembangan Kehutanan Sulawesi.

[8] Wakka, A. K. 2010. "Konsep Kemitraan dalam Pengelolaan Kawasan Hutan dengan Tujuan Khusus (KHDTK) Mengkendek". In Prosiding Ekspose Balai Penelitian Kehutanan Makassar. Bogor: Pusat Penelitian dan Pengembangan Konservasi dan Rehabilitasi. Badan Penelitian dan Pengembangan Kehutanan.

[9] Wakka, A. K. 2014. "Analisis Stakeholders Pengelolaan Kawasaan Hutan Dengan Tujuan KHusus (KHDTK) Mengkendek, Kabupaten 
Tana Toraja, Provinsi Sulsesi Selatan". Jurnal Penelitian Kehutanan Wallaceae, 3(1), 47-56.

[10] Wakka, A. K., \& Hapsari, E. 2011. "Kondisi Sosial dan Ekonomi Masyarakat di KHDTK Mengkendek Kabupaten Tana Toraja". In Prosiding Ekspose Balai Penelitian Kehutanan Makassar. Bogor: Pusat Penelitian dan Pengembangan Konservasi dan Rehabilitasi. Badan Penelitian dan Pengembangan Kehutanan.

[11] Wakka, A. K., \& Bisjoe, A. R. H. 2017. "Dinamika Pengelolaan Konflik Kawasan Hutan dengan Tujuan Khusus (KHDTK) Mengkendek, Kabupaten Tana Toraja, Sulawesi Selatan". In Kumpulan Abstrak Seminar Nasional Tahunan dan Kongres Komunitas Manajemen Hutan Indonesia (Komhindo III) (p. 3). Tanggal 3-4 Nopember 2017. Palangka Raya: Universitas Muhammadiyah Palangkaraya.

[12] Adnan, H., Berliani, H., Hardiyanto, G., Suwito, \& Sakti, D. K. 2015. "Pemberdayaan Masyarakat melalui Kemitraan Kehutanan. Panduan." Jakarta: Kemitraan bagi Pembaruan Tata Pemerintahan di Indonesia (The Partnership for Governance Reform).

[13] Adnan, H., Hertiadhi, R., Hardiyanto, G., \& Suwito. 2015. "Meretas Jalan Kemitraan: Implementasi Program Pemberdayaan Masyarakat melalui Kemitraan Kehutanan antara PT Arangan Hutan Lestari dengan Masyarakat Kecamatan VII Koto, Tebo, Jambi". Jakarta: Kemitraan bagi Pembaruan Tata Pemerintahan di Indonesia (The Partnership for Governance Reform)".

[14] Baum, F., MacDougall, C., \& Smith, D. 2006. "Participatory Action Research". J Epidemiol Community Health, 60 (10), 854 - 857. http://doi.org/10.1136/ jech.2004.028662

[15] Bergold, J., \& Thomas, S. 2012. "Participatory Research Methods: A Methodological Approach in Motion". Forum: Qualitative Social Research, 13(1), Art. 30.

[16] Kemmis, S., \& McTaggart, R. 2008. "Participatory Action Research: Communicative Action and the Public Sphere. In N. K. Denzin \& Y. S. Lincoln (Eds.), Strategies of Qualitative Inquiry" (3nd ed., pp. 271-330). Thousand Oaks, CA: Sage Publication, Inc.

[17] Subandi. 2011. "Deskripsi Kualititatif Sebagai Satu Metode Dalam Penelitian Pertunjukan". Harmonia: Jurnal Pengetahuan Dan Pemikiran Seni, 11(2), 17-179.

[18] Kurniawan, D., \& Syani, A. 2014. "Faktor Penyebab, Dampak dan Strategi Penyelesaian Konflik Antar Warga di Kecamatan Way Panji Kabupaten Lampung Selatan". Jurnal Sosiologi, 15(1), 1-12.

[19] Marina, I., \& Dharmawan, A. H. 2011. "Analisis Konflik Sumberdaya Hutan di Kawasan Konservasi". Sodality: Jurnal Transdisiplin Sosiologi, Komunikasi, Dan Ekologi Manusia, 5(1), 90-96.

[20] Wakka, A. K., \& Bisjoe, A. R. H. 2018a. "Dinamika Pengelolaan Konflik Kawasan Hutan dengan Tujuan Khusus (KHDTK) Mengkendek, Kabupaten Tana Toraja, Sulawesi Selatan". In Prosiding Seminar Nasional Tahunan dan Kongres Komunitas Manajemen Hutan Indonesia (Komhindo III). Palangka Raya: Universitas Muhammadiyah Palangkaraya.

[21] Wakka, A. K., \& Bisjoe, A. R. H. 2018b. "Peningkatan Modal Sosial Masyarakat Dalam Penyelesaian Konflik Melalui Mediasi: Kasus KHDTK Mengkendek, Kabupaten Tana Toraja". Jurnal Penelitian Sosial Dan Ekonomi Kehutanan, 15(2).

[22] Andriany, D. 2015. "Pengembangan Model Pendekatan Partisipatif Dalam Memberdayakan Masyarakat Miskin Kota Medan Untuk Memperbaiki Taraf Hidup". In Seminar Nasional Ekonomi Manajemen Dan Akuntansi (SNEMA) Fakultas Ekonomi Universitas Negeri Padang. Padang: Universitas Negeri Padang.

[23] Sanusi, H., \& Hidayah, A. K. 2015. "Pengkajian Potensi Desa Dengan Pendekatan Partisipatif Di Desa Mawai Indah Kecamatan Batu Ampar Kabupaten Kutai Timur". Jurnal AGRIFOR, 14(2), 185-196.

[24] Sinaga, D., Winoto, Y., \& Perdana, F. 2016. "Membangun Komunikasi Partisipatif Masyarakat Upaya Melestarikan Tanaman Salak Lokal Di Manonjaya Tasikmalaya". JURNAL KAJIAN INFORMASI \& PERPUSTAKAAN, 4(2), 191-202. 